\title{
NILAI NILAI SEJARAH TOPONIM WILAYAH KABUPATEN LAHAT SEBAGAI SUMBER PEMBELAJARAN SEJARAH
}

\author{
${ }^{1}$ Atika Rahmania Putri, ${ }^{2}$ Sukardi, ${ }^{3}$ Kabib Sholeh \\ 1,2,3 FKIP Universitas PGRI Palembang \\ atikarjailili@gmail.com
}

\begin{abstract}
Abstrak
Sejarah toponim pada suatu wilayah sangat penting untuk diketahui dan dipelajari oleh siswa-siswi sebagai pembalajaran sejarah kelokalan. Untuk saat ini sejarah toponim wilayah kota Lahat belum banyak diketahui nilai-nilai sejarah yang terkandung pada tempat tersebut terutama bagi masyarakat luas, padahal kota Lahat merupakan wilayah yeng menyimpan nilai-nilai sejarah dalam perjalanannya hingga seperti sekarang ini. Pada sisi lain nilai sejarah toponim ini juga dapat dijadikan sumber pembalajaran sejarah yang menarik. Adapun tujuan pada penelitian ini adalah untuk mengetahui dan menganlsis nilai-nilai sejarah toponim wilayah kota Lahat. Metode yang digunakan adalah metode sejarah (historis), mulai dari heuristic atau pengumpulan data melalui wawancara, observasi, dokumentasi, studi Pustaka. Langkah kedua adalah ferivikasi data, Teknik analisis datanya menggunakan interpretasi sejarah atau penafsiran sejara. Langkah terakhir adalah historiografi atau penulisan sejarah. Hasil penelitian adalah terdapat toponim wilayah yang mengandung nilai-nilai sejarah penting bagi kota Lahat seperti toponim Jalan Balai Yasa Kreta Api, Pasar Belande, Terowongan Gajah dan lain sebagainya. Pada toponim wilayah tersebut mengandung nilai-nilai sejarah seperti nilai perkembangan ekonomi kota lahat, nilai kemajuan tekhnologi dan nilai lainnya. Nilai-nilai sejarah toponim kabupaten kota Lahat dapat dijadikan sebagai sumber pembelajaran sejarah.
\end{abstract}

Kata Kunci: Nilai sejarah, Toponim, pembelajaran.

Abstract

The toponym history in a region is very important to be known and studied by students as a lesson in the history of locality. At present the toponym history of the Lahat city region is not widely known, the historical values contained in the place, especially for the wider community, even though the Lahat city is an area that stores historical values on its journey up to the present. On the other hand, this toponym historical value can also be an interesting source of historical learning. The purpose of this research is to find out and analyze toponym historical values of Lahat city area. The method used is the historical method (historical), starting from the heuristic or data collection through interviews, observations, documentation, literature study. The second step is data ferivication. The data analysis technique uses historical interpretation or historical interpretation. The final step is historiography or writing history. The results of the study are that there are regional toponyms that contain important historical values for the city of Lahat such as the toponym of Jl. Balai Yasa Kreta Api, Belande Market, Tunnel Gajah and others. The toponym of the region contains historical values such as the economic development value of the city, the value of technological progress and other values. The toponym historical values of Lahat city district can be used as a source of historical learning.

Keywords: Historical value, Toponym, learning. 


\section{PENDAHULUAN}

Dalam bahasa Inggris Toponym secara harfiah artinya nama tempat di muka bumi, "topos" adalah tempat atau permukaan seperti "topografi" adalah gambaran tentang permukaan atau tempat di bumi, dan "nym" dari "onyma" adalah nama, dan dalam bahasa Inggris kadang disebut "geographical names"(nama geografis) atau "place names" (Marini, 2019:11). Kemudian dalam kajian studi toponim ini memiliki unsur-unsur penting di dalamnya antara lain: unsur kesejarahan, unsur geografis, unsur kebudayaan Keilmuan toponim merupakan salah satu bidang ilmu yang mempunyai tugas khusus untuk meneliti mengapa suatu daerah di Nusantara ini memiliki nama nama yang sangat unik baik dari segi geografisnya maupun kesejarahannya hal ini menjadikan ilmu toponim menjadi istimewa (Sholeh, 2017:170). Mempertahankan nama tempat dari waktu ke waktu membutuhkan kekuatan kearifan lokal yang tinggi, karena mempertimbangkan nilai historis dari pada dinamika ruang. Jika mempertimbangkan dinamika keruangan maka bisa saja setiap toponim berubah sesuai dengan karakter yang ada saat itu (Marini, 2019: 11).

Salah satu nama toponim bernilai sejarah di kota Lahat adalah toponim Pasar Belande adalah sebuah pasar yang dulunya lokasi kuburan Cina akan tetapi dipindahkan tidak jauh dari lokasi pasar Belande. Kondisi tersebut dikarenakan semakin banyak orang Belanda yang datang ke kabupaten Lahat sehinggah terbentuk sebuah pasar yang diberikan nama pasar Belanda yang berada di tengah kabupaten kota Lahat. Namun sekarang pasar Belande di pindahkan kedaerah kelurahan Talang Jawa berdampingan dengan rel kereta api hingga kini lokasi lama pasar Belanda masih menjadi seuah pasar namun dengan kondisi yang berbeda dari sebelumnya.

Terdapat juga toponim wilayah kota Lahat seperti Jalan Balai Yasa Kreta Api, terowongan rel kereta api dan juga toponim lainnya yang sebagian besar memang toponim yang berada di kota Lahat mengandung nilai-nilai sejarah penting pada masa colonial Belanda pada saat pemerintahan Hindia Belanda berlangsung di Sumatera Selatan. Kondisi toponim-toponim kota Lahat tersebut sayangnya belum banyak diketahui atau dipelajari oleh masyarakat luas, padahal toponim kota Lahat mengandung nilai-nilai sejarah penting untuk dipelajarai sebagai bahan pengetahuan bagi masyarakat bagaimana pentingnya nilai-nilai toponim tersebut apabila dipelajari dengan baik maka akan menumbuhkan jiwa nasionalisme dan rasa semakin mencintai wilayah terutama kota Lahat Sumatera Selatan.

Sumber belajar yang dapat digunakan dalam pembelajaran Sejarah diantaranya tempat/lingkungan, benda, orang, buku peristiwa dan fakta (Meranti, 2013:34). Maka sumber belajar juga diartikan sebagai segala tempat atau lingkungan sekitar, benda, dan orang yang 
mengandung informasi dapat digunakan sebagai wahana bagi peserta didik untuk melakukan proses perubahan tingkah laku (Nugroho, 2013: 19-20).

Belajar adalah modifikasi atau memperteguh kelakuan melalui pengalaman. Menurut pengertian ini, belajar merupakan suatu proses, suatu kegiatan dan bukan suatu hasil atau tujuan. Belajar bukan hanya mengingat, akan tetapi lebih luas dari itu, yakni mengalami. Hasil belajar bukan suatu penguasaan hasil latihan melainkan pengubahan kelakuan (Hamalik, 2001:22). Dengan kurangnya sumber pembelajaran seperti sumber sejarah kelokalan yang diajarkan oleh seorang guru yang hanya mendapatkan dari beberapa sumber buku maka membuat pemahaman siswa menjadi tidak meluas sehingga dengan kurangnya pengentahun tentang pembelajaran sejarah dalam penelitian ini peneliti mampu menambahkan sumber pembelajaran sejarah kelokalan dan memperkaya sumber pembelajaran yang diuraikan dalam nilai-nilai sejarah toponim di kota Lahat sebagai sumber pembelajaran sejarah.

\section{METODE PENELITIAN}

Penelitian ini menggunakan metode Sejarah (metod historis), metode sejarah adalah proses menguji dan menganalisis secara kritis rekaman dan peninggalan masa lampau (Sjamsuddin, 2012:14). Adapun langkah-langkah awal penelitian ini yaitu; Pertama, heuristik atau dalam Bahasa Jerman Quellenkunde, adalah suatu kegiatan dalam mencari sumber untuk mendapatkan data-data, atau materi sejarah, atau evidensi sejarah (Sjamsuddin, 2012:67). Peneliti mengumpulkan data (heuristic) sumber sejarah di lapangan, observasi, wawancara, dokumentasi atau data kepustakaan, yang relevan lainnya. Kedua, verifikasi atau lazim disebut juga dengan kritik sumber untuk memperoleh keabsahan sumber yang benar-benar valid. Dalam hal ini kritik sumber terbagi menjadi dua yaitu kritik ekstern dan kritik intern.

Ketiga, untuk menganalisis data yang sudah dikumpulkan dari berbagai sumber yang sudah diverifikasi, maka kegiatan ketiga ini peneliti melakukan interpretasi (penafsiran) atau disebut juga tahap analisis data. Interpretasi atau penafsiran sejarah sering kali disebut juga dengan analisis sejarah atau penafsiran (Sjamsuddin, 2012:123). Interpretasi sejarah atau Teknik analisis datanya menggunakan interpretasi dengan pendekatan berbagai aspek bidang keilmuan seperti pendekatan arkeologis, geografis, ekonomologis, sosiologi, teologis antropologis dan interpretasi sintesis.

Keempat, sebagai tahap terakhir dalam metode sejarah adalah historiografi, historiografi adalah cara penulisan, pemaparan, atau pelaporan hasil penelitian sejarah yang telah dilakukan (Abdurrahman, 1999:67). Pada tahapan terakhir dalam penelitian ini, peneliti melakukan penulisan sejarah dengan tujuan hasil yang ditulis dapat memberikan gambaran yang jelas 
mengenai proses penelitian dari awal sampai akhir. Berdasarkan penulisan tersebut akan dapat dinilai apakah penelitiannya berlangsung sesuai dengan prosedur yang dipergunakannya atau tidak, memiliki validitas dan reliabilitas yang memadai atau tidak, sehingga penulisan sejarah itu akan dapat ditentukan mutu penelitian sejarah itu sendiri

\section{HASIL DAN PEMBAHASAN}

\section{Sejarah Toponim Kecamatan Kota Lahat}

\section{Terowongan Gunung Gajah}

Kecamatan kota Lahat merupakan kota kecil yang memiliki sejarah panjang sehingga nama-nama tempat yang mengandung nilai sejarah banyak tersebar di kota Lahat. Peninggalan seperti bangunan terowongan yang merupakan peninggalan kolonial Belanda yang dibangun pada tahun 1928/1929 yang dibangun oleh seorong arsitek Belanda bernama Willem Synja Tunnel namun pembangunan ini sempat terhenti hingga dibuka kembali pada tahun 1952.

Menerut seorang warga asli Gunung Gajah, Poniman (64 thn) merupakan ketua RW di kelurahan Gunung Gajah, sekaligus salah satu mantan mandor pembangunan terowongan kereta Api Indonesia bahwa pembangunan terowongan sempat terhenti menurutnya pemberhentian pembangunan ini dikarenakan dahulunya sering terjadinya pemberontakan perampokan yang dilakukan oleh segerombolan orang dikarenakan pada masa itu mengalami kesusahan faktor ekonomi, namun setela beberapa tahun dibuka kembali dalam pembanguan ini.
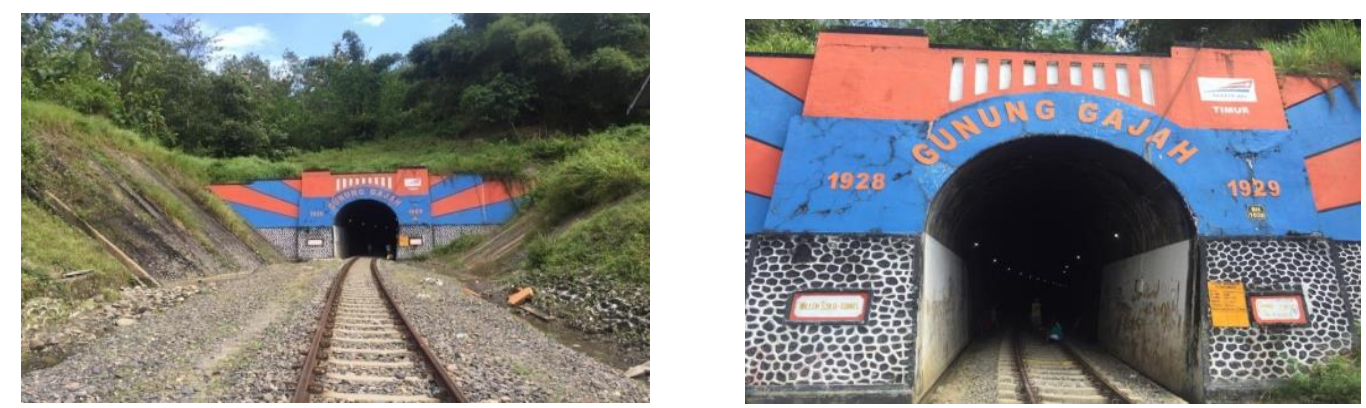

Gambar 1. Terowongan Gunung Gajah Kec, Lahat (Sumber: Dokumentasi pribadi, 2020).

Terowongan Gunung Gajah ini dulunya merupakan hutan namun sudah ada beberapa permukiman penduduk. Penamaan terowongan Gunung Gajahkarena dahulu kala adanya hewan gajah yang bertempat tinggal dihutan tersebut. Maka dari itu warga sekitar menyebutnya dengan sebutan terowongan Gunung Gajah beberapa tahun belakangan. Poniman mengatakan bahwasanya terowong ini merupakan terowongan terpanjang yang ada khususnya didaerah kecamatan/kota Lahat yang memiliki panjang 368 meter. 
Dengan adanya pembangunan terowongan memiliki tujuan untuk mudahnya transportasi yang digunakan pada masa kolonial Belanda sebagai alat transportasi pengangkut barang dagangan masa kolonial bahkan sekarang bermanfaat bagi masyarakat kabupaten Lahat sebagai alat transportasi antara Kota dan menjadi mata pencaharian dalam bidang ekonomi penduduk kecamatan Kota Lahat dan masyarakat sekitar. Terowong ini memiliki nilai seni bangunan tersendiri dapat dilihat dari seni bangunan yang berdiri kokoh dan megah, meskipun banyaknya aura mistik yang terjadi disekitar terowongan, beliau membenarkan tapi sampai saat ini untuk warga sekitar dan warga lainnya yang tinggal didaerah tersebut tidak merasa terganggu atau pun merasa tidak nyaman dengan keberadaan terowongan Gunung Gajah dan kini terowongan Gunung Gajah masih beroprasi secara normal tanpa hambatan apa pun.

\section{Jalan Balai Yasa Rumah Dinas Pekerja Jawatan Kereta Api (Balai Yasa)}
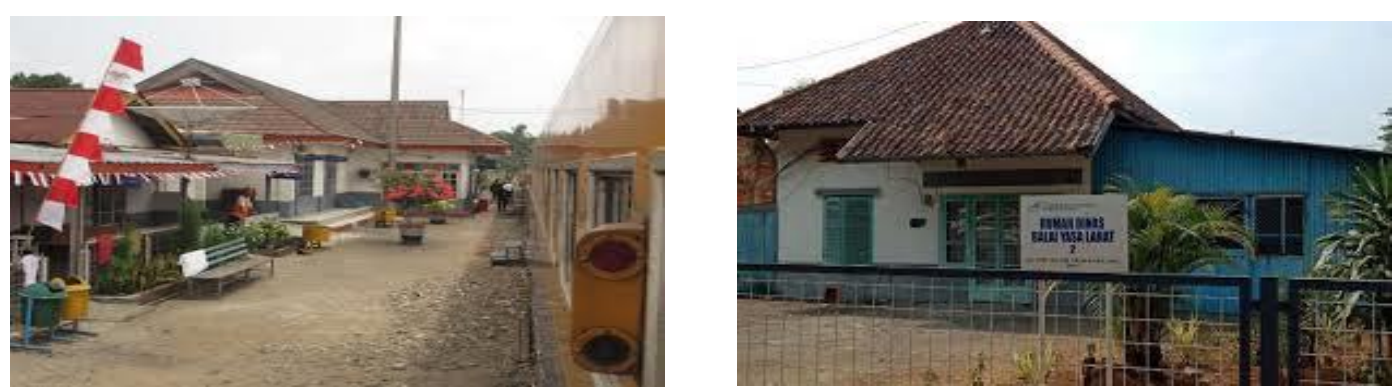

Gambar 2. Foto Jl. Balai Yasa Rumah Dinas PJKA Lahat (Sumber Dokumentasi pribadi:2020)

Balai yasa atau Perumahan Rumah dinas jawatankereta api yang sering disebut (RDKPJKA atau Perumahan Balai Yasa)berdiri tahun 1931 hingga saat ini yang masih beroprasi dan masih digunakan oleh karyawan dan staf PT Kereta Api, Menurut seorang pensiunan PT Kereta Api yang bernama Wasan 66 tahun beliau mengatakan bahwasannya Balai Yasa atau rumah dinas ini dibangun seiring berjalan pembangunan terowongan dimasa kolonial Belanda sebagai tempat tinggal karyawan dan staf dan dahulunya perumahan ini pernah ditinggali oleh orang-orang Belanda pembangunan ini dibangun oleh orang Belanda dan boleh ditempati oleh karyawannya dan perumahan ini hanya ditempati oleh pegawai dan tidak boleh menjadi hak milik (Kesuma, 2019:23).

Mereka boleh menempati sampai kapan pun dengan membayar sewa tanah terhadap PT Kereta Api merupakan kebijakan perusahaan, dan rumah dinas ini dibangun dengan seiring berjalannya pembangunan terowongan Gunung Gajah.Peninggalan rumah dinas ini merupakan bukti peninggalan kolonial Belanda yang masih bermanfaat sampai saat ini dan masih dipergunakan oleh staf dan karyawan PT Kereta Api Indonesia khususnya daerah kabupaten 
Lahat sebagai sarana dan prasarana yang dapat digunakan dengan baik oleh karyawan dan staf PT Kereta Api kabupaten Lahat.

\section{Sungai Lematang Lahat}
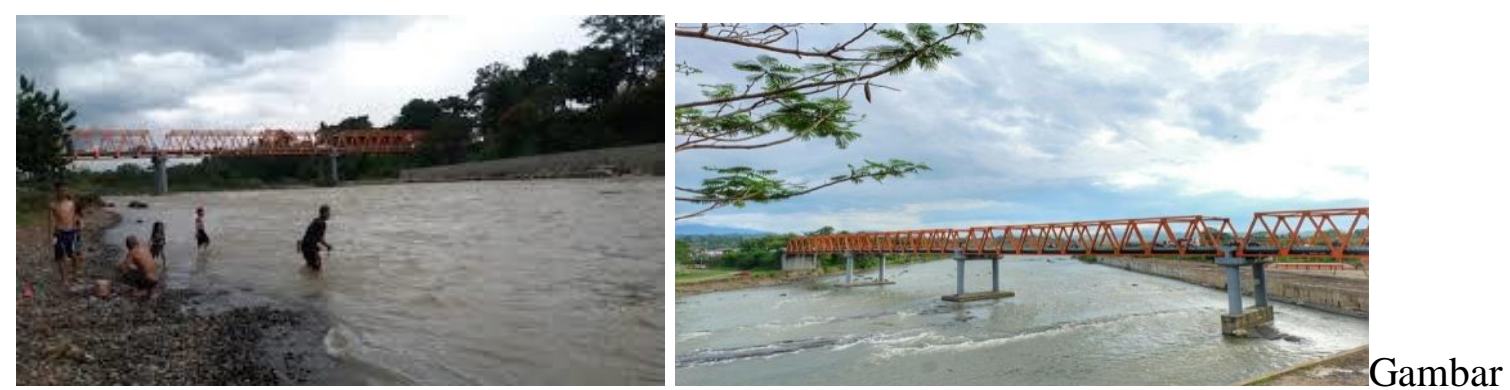

4.2.3. Sungai Lematang Kabupaten Lahat (Sumber dokumentasi pribadi :2020)

Kecamatan kota Lahat memiliki sebuah sungai yang cukup panjang yang digunakan masyarakat Lahat sebagai tempat mencari nafkah untuk memenuhi kebutuhan ekonomi sungai itu bernama sungai Lematang menerut seorang warga kota lahat yang bertempat tinggal tidak jauh dari sungai Lematang yang bernama Alamin 58 tahun beliau menuturkan bahwasannya pada zaman dahulu sungai ini pernah ditemukan sebuah perahu biduk, ditemukannya perahu biduk dikarenakan sungai ini sering dilewati kapal roda lambung yang menelusuri daerah dan singgah untuk menjual barang dagangan.

Dari sini pula asal muasal lahir nama kota Lahat yaitu ketika kapal meninggalkan daerah ysng disinggahinya dengan sebutan orang setempat LARAT (pergi), dari sini juga timbul nama sungai Lematang dimana Sungai ini dulunya merupakan tempat terjadinya sebuah pertempuran yang sengit antara pasukan Lim keturunan bangsa China dan keponakan Atung Bungsu seorang yang cukup sakti kala itu. Yang pada akhirnya pertempuran tersebut dimenangkan oleh Atung Bungsu kedua tokoh Lim dan Atung adalah awal mula terbentuk nama Sungai Limatung atau dikenal dengan Sungai Lematang (Wawancara, 2020).

Sungai lematang menglami kedangkalan sehingga para pedagang Belanda tidak dapat menggunakan perhau roda lambung sehingga mereka menggunakan perahu untuk hilir mudik bahkan termasuk tokoh penyebaran islam yaitu 'Raden Fatah' Raja Demak bahkan memiliki keterununan yang dikenal dengan suku Liem dengan buktiny ada makam Raden Fatah di desa Pagar Batu kecamatan Pulau Pinang Kabupaten Lahat terkubur kuku dan rambutnya maka dari sini muncul nama sungai lematang yang diambil dari suku Liem atau Limatung karna dan masyarakat lahat menyebutnya dengan sebutan sungai Lematang. 


\section{Pasar Belande Kota Lahat}
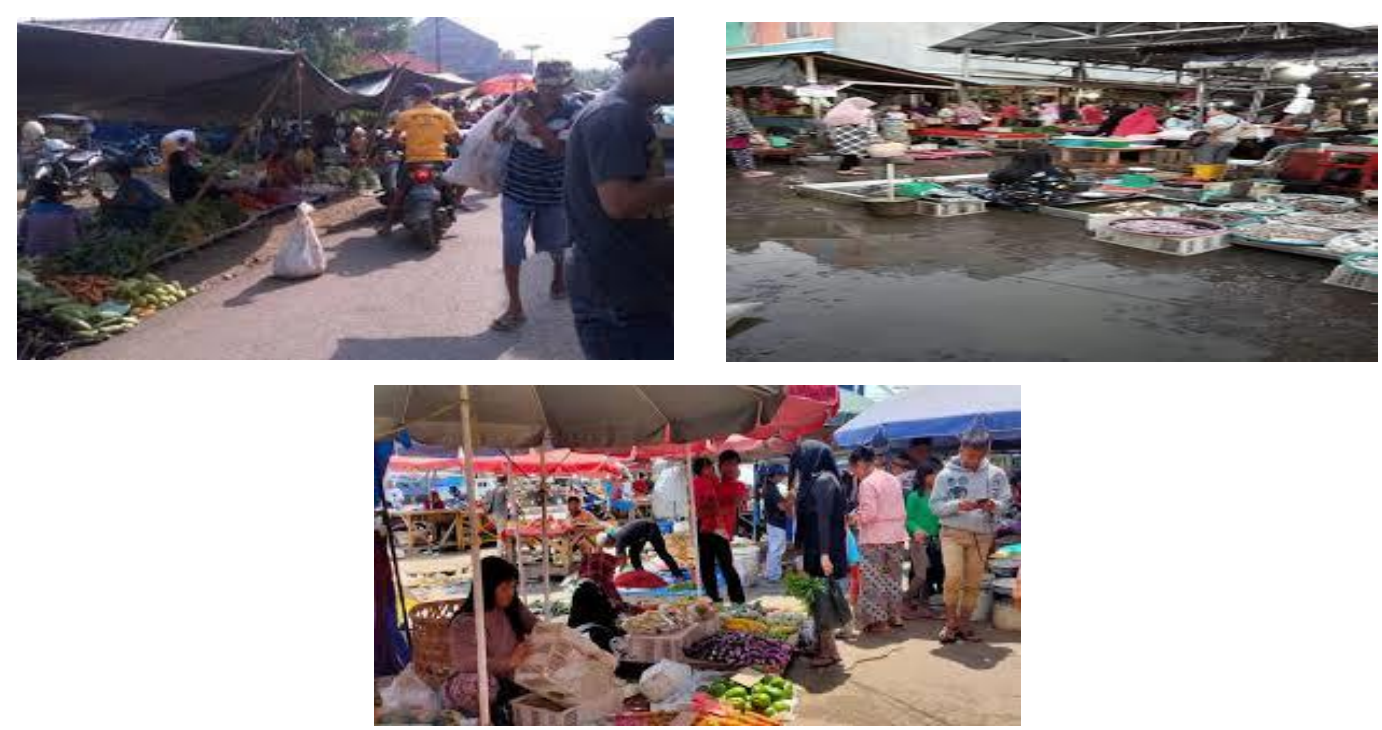

Gambar 4. Pasar Belande Kota Lahat (Sumber Dokumentasi pribadi, 2020)

Kabupaten Lahat kaya akan hasil Buminya dan Peninggalannya seperti peninggalan masa kolonial Belanda yang berada ditenga-tengah kecamatan kota Lahat yaitu sebuah pasar yang disebut dengan sebutan Pasar Belande menurut seorang warga yang bernama Lina 58 tahun seorang pedagang beliau menuturkan bahwasaanya Pasar Belande dahulunya pada masa kolonial Belanda dimana masa pembangun terowongan pada tahun 1928/1929 banyaknya pendatang pedagang maupun pekerja yang datang ke kota lahat dengan adanya pembangun terowongan yang sempat terhenti dikarenakan adanya pemberontokan maka banyak orangorang Belanda yang meninggal dunia dan dimakamkan ditengah kecamatan kota Lahat.

Dengan banyaknya orang-orang Belanda yang meninggal dan dimakamkan didaerah tersebut maka masyarakat Lahat menyebutnya dengan sebutan kuburan Belande, kemudian semakin banyaknya pendatang yang datang dan memiliki tempat tersendiri untuk melakukan perdagaan sehingga kuburan orang Belande dipindahkan dan dibongkar untuk dijadikan sebuah pasar yang sampai sekarang disebut masyarakat kabupaten Lahat sebagai pasar Belande kini lokasi pasar Belande menjadi tempat perdagangan masyarakat Lahat dan kini pasar Belande berubah menjadi Pasar Kaget yang mulai buka jam 14.00 WIB pasar Belande kini dipindahkan tidak jauh dari lokasi pasar Belande terdahulu yang kini disebut masyarakat Lahat pasar Kaget. 


\section{Jalan Talang Jawa Lahat}

Sejarah kereta api di Hindia Belanda bermula pada 1864 di Jawa. Sementara pembangunan rel kereta api di Sumatra dimulai di Aceh (1874), Sumatera Utara (1886), Sumatera Barat (1891), dan Sumatera Selatan (1914) (Sholeh, 2019:254). Di Sumatra Selatan, Staatsspoorwegen, sebuah perusahaan kereta api Hindia Belanda, memulai membangun jalur kereta dari Muara Enim hingga Lahat pada 1924. Baru pada 1931 dibangunlah Werkplaats kini dikenal sebagai Balai Yasa Lahat yang fungsinya sebagai jasa pelayanan perbaikan gerbong kereta dan lokomotif, juga jasa lainnya yang berkaitan dengan bengkel perkeretaapian. Kereta api telah mengubah wajah Lahat. Warga kota pun menyakini kaitan sejarah Talang Jawa, sebuah kampung orang-orang Jawa di tengah Kota Lahat.

Menurut seorang warga Kecamatan Kota Lahat dan juga seorang guru sejarah Nina Oktaviani serta ketua Rt Talang Jawa beliau mengatakan bahwasanya perkampung atau kelurahan Talang Jawa dahulunya pada masa pembangunan Terowongan Gunung Gajah 1928/1929 kota lahat kedatangan kuli-kuli asal Purwore Jawa Tengah pada masa Hindia Belanda. Konon, para kuli asal Jawa itu dihimpun untuk bekerja di bengkel kereta api dan pembangunan rel kereta api serta Terowongan Gunung Gajah Kemudian mereka membangun perkampungan di sebelah tempat bekerja mereka yang kini bertoponim Talang Jawa dikarenkan para kuli ada yang membawa keluarga serta ada yang menikah dengan orang lahat maka orang lahat menyebut kawan tersebut dengan sebutan kelurahan Talang Jawa yang merupakan orang orang Jawa yang bertempat tinggal didaerah tersebut dan bahasa yang digunakan mereka merupakan bahasa campuran bahasa kabupaten Lahat dan bahasa Jawa hingga kini keturunan Jawa semakin banyak di kabupaten Lahat khususnya kelurahan Talang Jawa.

\section{Nilai-nilai Sejarah Toponim Kecamatan Kota Lahat}

\section{Nilai Nasionalisme Kota Lahat}

Berbicara kolonialisme dalam konteks sejarah Indonesia, ia adalah perwujudan dari bentuk keserakahan, ketidakadilan, kebengisan, diskriminasi, dan penafian atas hak asasi manusia. Adapun, jika menengok kebelakang, bahwa bangunan nasionalisme yang pernah ditegakkan oleh para pejuang, pahlawan, dan pendiri bangsa ini, adalah nasionalisme yang anti terhadap kolonialisme, artinya nasionalisme yang terbangun untuk mewujudkan bagaimana bangsa ini merdeka dan bebas dari belenggu kolonialisme. Diketahui bahwa secara umum mindividu harus diserahkan kepada negara kebangsaan. Perasaan sangat mendalam akan suatu ikatan yang erat dengan tanah tumpah darahnya, dengan tradisi-tradisi setempat dan penguasa- 
penguasa resmi di daerahnya selalu ada di sepanjang sejarah dengan kekuatan yang berbedabeda (Miftahudin,2016:3)

Dalam pembahasaan di atas dengan adanya pembahsaan terhadap nilai-nilai sejarah toponim terowong Gunung Gajah yang ada di Kabupaten Lahat tepatnya di kecamatan kota Lahat memiliki nilai sejarah yang cukup dalam dimana terowong ini merupakan peninggalan kolonial Belanda pada masa jajahannya, bangunan ini memiliki nilai seni bangun yang bernilai tinggi. Terowongan ini bahkan menjadi alat transportasi bagi kolonial Belanda dalam perdagangan pada masa jajahannya dan masih beroprasi hingga kini dan menarik perhatian bagi penulis untuk mengetahui lebih mendalam sehigga dapat dijadikan sebagai pacuan untuk masyarakat umum bahwasannya kebupaten Lahat menyimpan nilai sejarah yang berguna bagi nusa dan bangsa dan bemanfaat dan dapat digunakan untuk menambah wawasan dan sumber pembelajarn bagi masyarakat kabupaten Lahat agar tertingkatnya rasa cinta dan bangga terhadap tanah air.

Begitu pun juga dengan sungai Lematang yang dulunya tempat terjadinya pertempuran antara orang China suku Liem dan Atung Bungsu sehinggah sungai tersebut disebut menjadi sungai Limatung dan masyarakat Lahat menyempurnakan sebutan sungai Lematang dan memiliki nilai sejarah masa kolonial China dimana kita memenangkan pertempuran hingga kini sungai Lematang masih bermanfaat bagi masyarakat kabupaten Lahat khususnya bagi kemacatan kota Lahat sebagai tempat mata pencaharian sehari-hari. Bagi generasi muda agar lebih menumbuhkan rasa cinta dan peduli terhadap tanah kelahiran dan menjadi acuan untuk mengenal nilai-nilai bersejarah yang ada di daerah sekitar.

\section{Nilai Perkembangan Ekonomi Kota Lahat}

Ekonomi secara umum dapat didefinisikan sebagai suatu ilmu yang mempelajari perilaku manusia dalam pemanfaatan sumber daya yang langka dalam proses maksimalisasi produksi maupun maksimalisasi utilitas individu. Ekonomi konvensional berbasis pada peningkatan efisiensi dalam perekonomian dengan mendasarkan penetapan segala sesuatu berdasarkan mekanisme yang terjadi di pasar, namun hal ini berakibat pada penumpukan modal dan kekayaan pada sekelompok individu atau kelompok yang memiliki kekuatan akses dan jaringan (Arif, 2017:1).

Hal inilah yang kemudian menimbulkan beberapa permasalahan yang mengakibatkan perlunya perbaikan menyeluruh terhadap sistem ekonomi yang ada. Fakta memperlihatkan bahwa berbagai teori dalam ekonomi terutama berkaitan dengan pembangunan ekonomi dalam masyarakat tidak mampu mewujudkan ekonomi yang berkeadilan dan membawa kesejahteraan bagi seluruh masyarakat (Arif, 2017:1-2) 
Dengan adanya peninggalan bersejarah di kabupaten Lahat menjadi nilai toponim wilayah kabupaten Lahat sebagai tempat perekonomian bagi msyarakat kabupaten Lahat tepatnya bagi masyarkat kecamatan kota Lahat dimana dengan adaya peninggalan seperti sungai Lematang dan pasar Belande peninggalan masa kolonial menjadi sumber mata pencaharian sehari-hari, untuk memenuhi kebutuhan hidup masyarakat kabupaten Lahat dengan memanfaatkan hasilnya seperti disungai Lematang masyarakat memanfaatkan seperti membangun wisata dipinggir sungai dan memanfaatkan sungai lematang dengan semestinya untuk memenuhu kebutuhan hidup masyarakat untuk memenuhi kebutuhan hidup. Kemudian juga dengan pasar Belande menjadi tempat pencaharian kebutuhan untuk memenuhi perekonomiam masyarakat kabupaten Lahat khusunya bagi masyarakat kecamatan kota Lahat, keduannya merupakan peninggalan yang masih dapat dimanfaatkan oleh masyarakat hingga sekarang untuk memenuhi kebutuhan hidup.

\section{Nilai Perkembangan Teknologi Kota Lahat}

Kemajuan teknologi saat ini tidak bisa dipisahkan dari kehidupan masyarakat. Berbagai informasi yang terjadi di berbagai belahan dunia kini telah dapat langsung kita ketahui berkat kemajuan teknologi (globalisasi). Tentu kemajuan teknologi ini menyebabkan perubahan yang begitu besar pada kehidupan umat manusia dengan segala peradaban dan kebudayaannya. Perubahan ini juga memberikan dampak yang begitu besar terhadap transformasi nilai - nilai yang ada di masyarakat. Khususnya masyarakat dengan budaya dan adat ketimuran seperti Indonesia. Saat ini, di Indonesia dapat kita saksikan begitu besar pengaruh kemajuan teknologi terhadap nilai - nilai kebudayaan yang di anut masyarakat, baik masyarakat perkotaan maupun pedesaan (modernisasi). Kemajuan teknologi seperti televisi, telepon dan telepon genggam (HP), bahkan internet bukan hanya melanda masyarakat kota, namun juga telah dapat dinikmati oleh masyarakat di pelosok - pelosok desa ( Wahyudi, 2014:13).

Kemajuan teknologi juga dirasakan oleh masyarakat kabupaten Lahat pada masa kolonial Belanda dimana pada masa itu dengan minimnya keterbatasan akan dunia pendidikan, masyarakat kabupaten Lahat sudah mengenal alat transportasi yang baik dimana dengan dibangunnya sebuah perusahan Kereta Api dimana pada masa itu kendaran belum terlalu banyak dan yang memiliki kendaran berteknologi tinggi hanya dikalangan petinggi kolonial. Tetapi msyarakat kabupaten Lahat sudah dikenalkan dengan teknologi yang dibawah oleh kalangan penjajah sebagai alat transportasi mereka dan juga menjadi mata pencaharian bagi mereka yang hingga kini peninggalan tersebut masih bermanfaat dan beroprasi serta menjadi lahan mata pencaharian bagi masyarakat kabupaten Lahat. Merupakan nilai teknologi yang tinggi yang menjadi peninggalan kolonial Belanda dan memiliki nilai sejarah bagi masyarakat 
awam dan dalam dunia pendidikan bahwasaanya kolonial Belanda meninggalkan peninggalan teknologi yang hingga kini masih beroprasi hingga kini dan bermanfaat bagi bangsa teruta bagi masyarakat Kabupaten Lahat.

\section{Nilai Kearifan Lokal Kota Lahat}

Adat istiadat dan tata nilai yang ada dalam suatu masyarakat merupakan basis dalam mengatur tata perikelakuan anggota masyarakat. Rasanya akan banyak kehilangan sesuatu yang berharga apabila kekayaan adat istiatat dan budaya yang ada di kawasan Nusantara tidak dipelihara dan dikembangkan. Untuk itu perlu upaya penggalian terhadap apa yang disebut dengan istilah nilai-nilai kearifan lokal. Sebagaimana dikemukakan (Maryani, 2011:1) bahwa: "Dalam penjelajahan jaman untuk mencapai tujuan karena kearifannya menjadi suatu kebutuhan budaya lokal yang unggul harus dipandang sebagai warisan sosial. Manakala budaya tersebut diyakini memiliki nilai yang berharga bagi kebanggaan dan kebesaran martabat bangsa, maka transmisi nilai budaya kepada generasi penerus merupakan suatu keniscayaan"

Dengan adaya peninggalan kolonial Belanda dalam toponim wilayah Kabupaten Lahat sungai Lematang sebagai tempat hulu hilir mudik kolonial Belanda untuk melakukan perdagangan dan tokoh penyebaran islam Raden Fatah. Hingga kini sungai Lematang menjadi tempat pencaharian yang berlanjut dari masa kolonial hingga kini menjadi tempat perdagangan dan pencaharian hinga kini kearifan lokal budaya yang di bawah oleh kolonial terus berkembang dengan seiring berjalannya waktu daan kini sungai lematang yang memiliki sejarah menjadi tempat wisata sekaligus tempat masyarakat kabupaten Lahat memenuhi kebutuhan hidupnya.

\section{KESIMPULAN}

Sejarah toponim wilayah kota Lahat memiliki banyak nama-nama tempat yang mengandung sejarah penting seperti halnya J1 Balai Yasa PJKA Lahat, Jl Terowongan Gajah, Talang Jawa Lahat, sungai lematang dan lain sebagainya. Pada sejarah toponim tersebut tentu mengandung nilai-nilai sejarah penting yang sangat menarik untuk dipelajari seperti nilai nasionalisme masyarakat Lahat, nilai perkembangan ekonomi masyarakat Lahat, nilai perkembangan teknologi di kota lahat dan nilai kearifan lokal di kota Lahat. Dengan demikian nilai-nilai sejarah toponim kota Lahat dapat dijadikan sebagai sumber pembelajaran sejarah yang menarik dan penting bagi masyarakat luas. 


\section{DAFTAR PUSTAKA}

Abdurrahman, D. 1999, Metode Penelitian Sejarah. Jakarta: Logos Wacana Ilmu

Arif, M. Nur Rianto. 2010. Teori Makroekonomi Islam: Konsep, Teori dan Analisis. Bandung: Alfabeta.

Hendro S Wahyudi, M, PS, 2014. Teknologi dan kehidupan.

https://media.neliti.com/media/.publications/227634-teknologi-dan-kehidupanmasyarakat-7686f94.pdf, $1 \underline{3}$.

Hamalik, Oemar. 2001. Proses Belajar Mengajar. Jakarta : Bumi Aksara.

Kesuma, O. N., \& Sholeh, K. 2019. Nilai Sejarah Gereja Siloam Dalam Penyebaran Agama Kristen Di Kota Palembang Sebagai Sumber Pembelajaran Sejarah. Kalpataru Jurnal Sejarah dan Pembelajaran Sejarah, 5(1), 69-77.

Marini, M., Sholeh, K., \& Sukardi, S. 2019. Sejarah Toponim Prabumulih sebagai Sumber Pembelajaran Sejarah. SINDANG: Jurnal Pendidikan Sejarah Dan Kajian Sejarah, 1(2), 9-16.

Meranti, T. 2013. pembelajaran efektif untuk pelajaran sejarah. Jakarta Timur: Pt wadah Ilmu Sugiyono. 2011. metode penelitian kuantitatif kualitatif dan R\&D. Bandung: Alfabeta.

Miftahudin, 2016. Nasionalisme Indonesia. https://journal.uny.ac.id/index.php/.mozaik/article/donwload/43817,3.

Nugroho, Wicaksono Adi. 2013. Sumber belajar berpengaruh terhadap prestasi belajar. Discipline, learning skills and academic achievement. Journal of Arts and Education.

Sjamsuddin, H. 2012. Metodologi Sejarah. Yogya0karta: ombak

Sholeh, K. 2017. Prasasti Talang Tuo Peninggalan Kerajaan Sriwijaya Sebagai Materi Ajar Sejarah Indonesia Di Sekolah Menengah Atas. HISTORIA: Jurnal Program Studi Pendidikan Sejarah, 5(2), 175-194.

Sholeh, K., Srinindiati, D., Suriadi, A., Ahyani, N., Suryani, I., Zamhari, A., ... \& Idris, M. 2019. Nilai-Nilai Situs Bersejarah di Sumatera Selatan Sebagai Penguat Karakter di SMK PGRI Lahat. Jurnal PkM Pengabdian kepada Masyarakat, 2(03), 235-245. 